\title{
Journal of Applied Research and Technology
}

www.jart.icat.unam.mx

Journal of Applied Research and Technology 19 (2021) 49-65

Original

\section{Activated charcoal production from tree pruning in the Amazon region of Brazil for the treatment of gray water}

\author{
Marcelo M. Pedroza ${ }^{a \star}$ - Leonardo H. D. Neves ${ }^{\mathrm{b}}$ - Elaine C. S. Paz ${ }^{\mathrm{a}}$ \\ Fabrício M. Silvac ${ }^{c}$ Claudia S. A. Rezende ${ }^{a} \cdot$ Aymara G. N. Colen $^{c} \bullet$ Matheus G. Arruda ${ }^{a}$ \\ a Departamento de Meio Ambiente, Instituto Federal do Tocantins (IFTO) \\ ${ }^{b}$ Departamento de Engenharia Ambiental, Universidade Federal do Tocantins (UFT) \\ ${ }^{c}$ Departamento de Engenharia Ambiental, Faculdade ITOP
}

Received 0312 2020; accepted 09252020

Available 02282021

\begin{abstract}
The objective of this work was to obtain, through the tree pruning pyrolysis, coal to be used in the removal of pollutants present in gray waters. The coal obtained during the process was used in a gray water filtration column and dye adsorption test. In this investigation it was proposed the treatment of gray water by the following series steps: (a) coagulation/ flocculation, (b) decantation, (c) sand filtration and (d) coal filtration column. The maximum coal yield was $60.10 \%$ obtained at $360{ }^{\circ} \mathrm{C}$ and heating rate of $30^{\circ} \mathrm{C} / \mathrm{min}$. The gray water polishing using the coal obtained from the tree pruning pyrolysis process was efficient in the removal of the studied analytical parameters. For turbidity, COD, total solids and residual chlorine parameters, the removal values were 99, 98, 71 and $100 \%$, respectively. The charcoal from the filtration column was responsible for removing organ matter of gray water.
\end{abstract}

Keywords: Pyrolysis, tree pruning, coal, gray water, filtration column 


\section{Introduction}

Law No. 12,305 / 10, which establishes the National Solid Waste Policy (PNRS) in Brazil, contains important instruments to enable the country to advance in finding solutions to the main environmental, social and economic problems arising from the inadequate management of solid waste. This law provides for the prevention and reduction of waste generation, having as its proposal the practice of sustainable consumption habits and a set of instruments to increase the recycling and reuse of waste and the environmentally appropriate disposal of waste (Brasil, 2010; Gamelin et al., 2009; Nascimento et al., 2017; Pedroza et al., 2014).

Waste from urban tree pruning (public trees and private residences) in a municipality can generate serious urban problems when not properly utilized. The final disposal of these materials often occurs in improper locations such as landfills and clandestine dumps. In addition to waste resulting from pruning of public trees (trunks, branches, stumps and roots), urban plant waste also includes organic material from the maintenance of parks and gardens (including grass and various woody materials). Field surveys in the country have identified different experiences in the municipalities visited ranging from the lack of use of waste to high efficiency, which in this case allows to generate revenue for the city, reducing costs of maintaining the accumulation of organic material in landfills (Pedroza et al., 2011; Pedroza et al., 2014; Pedrosa et al., 2019).

The tree pruning residue generates a considerable amount of forest biomass, which can be harnessed energetically as solid fuel, no longer being an environmental liability, leading to economic and environmental gains of interest to society (Pedrosa et al., 2019). In this context, pyrolysis and briquetting are highlighted as a process of utilization of lignocellulosic residues derived from biomass, making it possible to use them as raw material in the substitution of firewood for an equivalent product (Cheng et al., 2018). The use of this type of waste is advantageous, since it is a renewable energy source, thus representing an alternative to traditional and polluting fossil fuels derived from oil (Cheng et al., 2018; Pedrosa et al., 2019).

The use of urban solid waste (RSU), highlighting tree pruning as a raw material in the production of activated carbon from the application of the pyrolysis process, is an environmentally viable alternative, with the advantages of preventing environmental impacts future, arising from the incorrect disposition of this waste in the environment, and for making it possible to obtain a product of economic and sustainable value (Kan et al., 2016; Makrigianni et al., 2017). The coal obtained in the process can be employed in the removal of heavy metals and toxic organic substances from effluents, replacing the commercial activated charcoal. In addition, it can be used in boilers and tubular ovens, commercial ovens (pizzeria, bakery, etc.) and domestic use (fireplaces and grills) (Gamelin et al., 2009; Nascimento et al., 2017; Pedroza et al., 2014).

Recently, the increase in demand and the decrease in the supply of quality water are some of the problems that have been affecting mainly the large urban agglomerations. It is necessary to develop technologies and alternative solutions, since the increase in population causes the demand for water resources to increase substantially. Decreasing the quality of aquatic bodies and disordered population growth are some of the factors that contribute to this scenario (Albalawneh \& Chang, 2015; Sahoo, 2018).

Gray water is any non-industrial wastewater that comes from domestic processes such as washing dishes, clothes and bathing. Gray water accounts for 50 to $80 \%$ of the residential total. Composite of wastewater generated from all sanitized homes except toilets (Bani-Melhem et al., 2015). In this sense, there is a need to stimulate practices, programs and policies that help preserve the quality and quantity of water, and may highlight the adoption of conservation activities such as the development of alternative sources for water supply, reuse of wastewater, artificial recharge of aquifers, the use of rainwater, etc. The reuse of gray water for non-potable purposes (flushing toilets, floor washing, car washing, garden irrigation) significantly reduces the demand for fresh water (BaniMelhem et al., 2015; Vieira et al., 2009).

The objective of this work was to obtain coal from the thermal degradation of pruning of trees and to verify its capacity to remove pollutants present in gray water.

\section{Materials and methods}

\subsection{Preparation of samples and characterization of the raw material}

Samples of pruning residues from trees were collected at the IFTO (Instituto Federal do Tocantins), in Palmas, Amazon region of Brazil, and transported in plastic bags identified for LARSEN (Laboratory of Innovation in Waste Utilization and Energy Sustainability). Two types of samples were prepared: (a) sample 1 (leaves and small branches) and (b) sample 2 (stem and materials of higher hardness). The drying of the residues was done at $60{ }^{\circ} \mathrm{C}$. All samples were ground in a knife mill and separated in $0.59 \mathrm{~mm}$ aperture sieves as a way to improve the homogeneity of the raw material. The samples were characterized by the following analytical variables: moisture (ASTM Method D 3173-85), volatile material, ash (Method ASTM D 2415-66), calorific value (in Parr 1341 calorimetric pump). The content of carbon, hydrogen, nitrogen, sulfur and oxygen was determined through a 2400 Series II CHNS/O Elemental Analyzer. The thermogravimetric tests and kinetic study of loss of material with sample were 
carried out. The levels of cellulose, hemicellulose and lignina were determined by Klason method. The micrographs were obtained using a Scanning Electron Microscope (SEM) with Energy Dispersive X-Ray Detector (EDX), model Leo 212i and EDS 5040. The infrared spectra covering the $4000-400 \mathrm{~cm}-1$ region were obtained in FTIR spectrophotometer, Thermo Nicolet, model Nexus 470.

\subsection{Tree pruning pyrolysis tests}

The procedures used in this study were divided into two stages, whose experimental conditions are found in Table 1.

Table 1. Experimental conditions used in tree pruning pyrolysis tests.

\begin{tabular}{ccc}
\hline Factors studied & Preliminary tests & $\begin{array}{c}\text { Central composite } \\
\text { rotatable design } \\
(\text { CCRD })\end{array}$ \\
\hline $\begin{array}{c}\text { Temperature }\left({ }^{\circ} \mathrm{C}\right) \\
\text { Heating rate } \\
\left({ }^{\circ} \mathrm{C} / \mathrm{min}\right)\end{array}$ & 500 e 600 & $\begin{array}{c}360,400,500,600 \mathrm{e} \\
640\end{array}$ \\
$\begin{array}{c}\text { Reaction time }(\mathrm{min}) \\
\text { Inert flow rate } \\
(\mathrm{mL} / \mathrm{min})\end{array}$ & 30 & $24,30,45,60$ e 66 \\
\hline
\end{tabular}

The biomass was introduced to the reactor in the form of briquette. The thermal conversion was carried out in a fixed bed reactor of quartz $(100 \mathrm{~cm}$ long and $10 \mathrm{~cm}$ external diameter). The reactor was heated by a reclining bipartite furnace. The reactor was operated in batch mode, with nitrogen being the inert gas used in the preliminary tests. With the objective of mass balance, after reaction and cooling of the experimental system, all the products of the process were collected, weighed and stored. The charcoal was recovered directly from the reactor and the liquids obtained during the process were recovered after the vapor condenser in the separating funnel. The Scanning Electron Microscopy assay of the obtained coal was carried out in equipment of model TM3000 with magnification of 500 and 2000x. The conditions employed in the Fourier transform Infrared spectroscopy assay in the coal obtained in the research were: range of 4000$400 \mathrm{~cm}-1,32$ scans / min in $\mathrm{KBr}$ pellet.

A multivariate planning study was carried out to verify the effects of two factors on the pyrolysis tree pruning system. An experimental design (Central composite rotatable design CCRD) was applied, with 3 experiments at the central point, with 11 types of combinations between the factors. The experiments were performed at random. The factors studied were: pyrolysis temperature and heating rate. The minimum and maximum values are presented in Table 2. These tests were carried out in fixed bed reactor.
Table 2. Levels of the Factors used in Experimental Planning, during Pyrolysis of pruning of trees.

\begin{tabular}{lccccc}
\hline Coded factors & \multicolumn{5}{c}{ Levels } \\
\cline { 2 - 6 } & $(-1,4)$ & $(-1)$ & $(0)$ & $(+1)$ & $(+1,4)$ \\
& & & & & \\
\hline Temperature $\left(\mathrm{X}_{1}\right)\left({ }^{\circ} \mathrm{C}\right)$ & 360 & 400 & 500 & 600 & 640 \\
Heating rate $\left(\mathrm{X}_{2}\right)\left({ }^{\circ} \mathrm{C} / \mathrm{min}\right)$ & 24 & 30 & 45 & 60 & 66 \\
\hline
\end{tabular}

\subsection{Dye adsorption test on coal column}

The adsorption studies were carried out in a fixed bed column, made of a PVC plastic pipe in the cylindrical format, with flow control at the entrance and exit, with the following dimensions: total pipe height $40 \mathrm{~cm}$, height of the coal in column $11 \mathrm{~cm}$, pipe diameter $2.0 \mathrm{~cm}$. In the system was used a mass of 6 grams of coal. The experiment was carried out in a continuous flow, using methylene blue solution $(5 \mathrm{mg} / \mathrm{L})$ with $\mathrm{pH}$ adjusted (7.0 \pm 0.2$)$ and at room temperature $(25 \pm 1)$, with the following liquid flow rates 2 e $5 \mathrm{~mL} / \mathrm{min}$ (Fig. 1).

The column feed was made by gravity. The adsorption of the dye solution was measured using a UV-Vis spectrophotometer at a wavelength of $650 \mathrm{~nm}$, using a calibration curve, constructed by analyzing solutions of concentrations equal to: 1, 5, 10,15 and $20 \mathrm{mg} / \mathrm{L}$, the known initial solution of methylene blue.

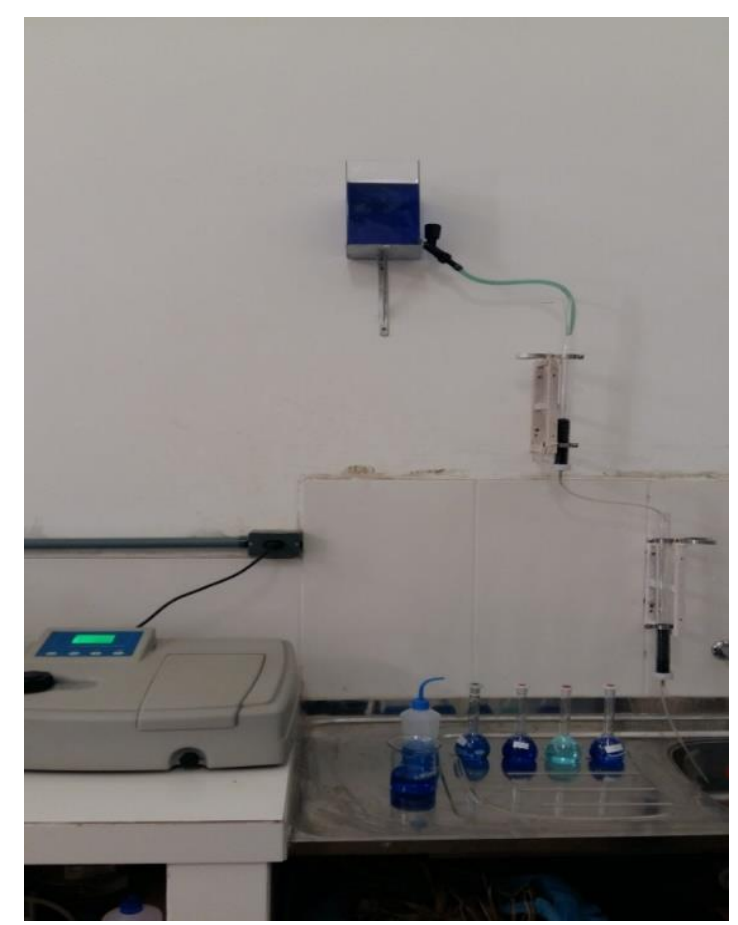

Figure 1. Fixed bed column adsorption test. 
The column feed was made by gravity. The adsorption of the dye solution was measured using a UV-Vis spectrophotometer at a wavelength of $650 \mathrm{~nm}$, using a calibration curve, constructed by analyzing solutions of concentrations equal to: 1, 5, 10, 15 and 20 $\mathrm{mg} / \mathrm{L}$, the known initial solution of methylene blue.

\subsection{Removal of pollutants from ash waters using sand and coal column obtained from the pyrolysis process of tree pruning}

The treatment adopted in this research was divided into two stages: (a) coagulation / flocculation / decantation process and (b) filtration of the coagulation system effluent in sand and activated carbon filter produced from tree pruning. Coagulation / flocculation / decantation assays were performed in a Jar Test apparatus, Ethiktechnology Brand, model 218-3LDB. The coagulation / flocculation tests were performed with raw gray water with $\mathrm{pH}$ correction to near neutrality $(\mathrm{pH}=7)$, using $\mathrm{HCl}$ solution $(0,5 \mathrm{~mol} / \mathrm{L})$. The chemical coagulant employed was aluminum sulfate (1\%).
Polishing domestic wastewater was carried out in this research. The system consists of a series of cylinders filled with sand and coal obtained from pyrolysis of tree pruning, operated on a continuous flow, made of a PVC plastic pipe in the cylindrical format, with the following dimensions: total pipe height $40 \mathrm{~cm}$, height of the coal in column $11 \mathrm{~cm}$, pipe diameter $2.0 \mathrm{~cm}$. The sand column, with 10 grams of the material in it, was fed with raw waste water, followed by the column containing 10 grams of coal. The system was operated with the following liquid flow rates $5 \mathrm{~mL} / \mathrm{min}$. The quality of the filtered effluent was monitored. For the accomplishment of the objectives of this stage of the research, samples were collected at four points: P1 - raw gray water, P2 - decanted gray water from the coagulation / flocculation system, P3 - sand filter effluent and P4 - coal filter effluent. The determinations followed the methods described in the Standard Methods for the Examination of Water and Wastewater - 19th edition (APHA / AWWA / WEF, 2005), as Table 3.

Table 3. Analytical methods applied in the physical-chemical characterization of gray water and effluent.

\begin{tabular}{ccc}
\hline Analytical parameter & Methodology & Reference (APHA, 2005) \\
\hline Temperature & Mercury thermometer & SMEWW 2550B \\
Turbidity & Electrometric & SMEWW 4500H ${ }^{+}$ \\
COD & nephelometric & SMEWW 2130B \\
Total solids & Colorimetric & SMEWW 5220D \\
Fixed solids & Gravimetric & SMEWW 2540B \\
Volatile solids & Gravimetric & SMEWW 2540E \\
Alkalinity & Gravimetric & SMEWW 2540E \\
Residual chlorine & Volumetric & SMEWW 2320B \\
\hline
\end{tabular}




\section{Results and discussion}

\subsection{Biomass and biochar characterization}

Table 4 shows the results obtained in the proximate and ultimate biomass and biochar analyzes. The moisture and ash contents of a fuel are important information in the characterization of a given fuel, since they are directly related to its calorific value. According to the literature (Bridgwater, 2012; Gamelin et al., 2009; Nascimento et al., 2017; Pedroza et al., 2011; Vieira et al., 2009), the higher the moisture and ash contents of the biomass, the lower its combustion power, and this is due to the process of evaporation of moisture, in which it absorbs energy during combustion. The ash content makes it difficult to transfer heat during fuel combustion, however volatile materials play an important role during ignition and the initial combustion stages of biomass (Bridgwater, 2012; Gamelin et al., 2009). The calorific value of sample 1 was much lower, $16.8 \mathrm{MJ} / \mathrm{kg}$, due to the higher moisture and ash contents of this sample. No sulfur content was observed in the samples analyzed, and this points to the use of this material as clean fuel.
It can be observed that, as the temperature increases, the carbon content increases proportionally and the oxygen and hydrogen contents decrease ostensibly (Bridgwater, 2012; Pedroza et al., 2017). As a consequence of the intense distillation promoted by the increase in temperature. The carbon content observed in charcoal obtained at $360{ }^{\circ} \mathrm{C}$ was $62.1 \%$, much higher than that observed in biomass (41.5\%). Oxygen content in coal decreased with increasing temperature from 360 to $640{ }^{\circ} \mathrm{C}$. The calorific value increases with the carbon concentration in the coal composition.

During the pyrolysis process of the biomass, at temperatures around $300-350^{\circ} \mathrm{C}$, moisture is removed and the hemicellulose is degraded, causing the release of acetic acid, phenol fractions and other compounds with low calorific value (Bridgwater, 2012; Gamelin et al. 2009; Pedroza et al., 2017). Lignin and cellulose also undergo rapid depolymerisation, and this justifies the decrease of the amount of volatile material in the composition of the samples of coal analyzed here, as well as a considerable increase in the fixed carbon content in the material. The volatile material content decreased from $80 \%$ (biomass) to $27.2 \%$ (coal obtained at $360^{\circ} \mathrm{C}$ ).

Table 4. Characteristics of the pruning waste and biochar.

\begin{tabular}{|c|c|c|c|c|}
\hline \multirow[t]{2}{*}{ Analytical parameter } & \multicolumn{2}{|c|}{ Pruning tree } & \multicolumn{2}{|c|}{ Biochars } \\
\hline & Sample 1 & Sample 2 & $360^{\circ} \mathrm{C}$ & $640^{\circ} \mathrm{C}$ \\
\hline \multicolumn{5}{|c|}{ Proximate analysis } \\
\hline Moisture (\%) & 6.4 & 6.6 & - & - \\
\hline Volatile matter (\%) ${ }^{\mathrm{a}}$ & 80.0 & 82.0 & 27.2 & 24.5 \\
\hline Ash (\%) & 6.5 & 2.1 & 17.1 & 18.3 \\
\hline Fixed carbon (\%) & 7.1 & 9.3 & 55.7 & 57.2 \\
\hline \multicolumn{5}{|c|}{ Ultimate analysis } \\
\hline Carbon (\%) & 41.5 & 44.7 & 62.1 & 77.6 \\
\hline Hydrogen $(\%)^{b}$ & 9.1 & 8.0 & 3.8 & 4.6 \\
\hline Oxygen (\%) & 48.5 & 46.9 & 33.2 & 17.8 \\
\hline Nitrogen $(\%)^{b}$ & $<1.0$ & $<1.0$ & $<1.0$ & - \\
\hline Sulphur (\%) & & - & - & - \\
\hline $\mathrm{HHV}(\mathrm{MJ} / \mathrm{kg})$ & 16.8 & 19.2 & - & 29.7 \\
\hline \multicolumn{5}{|c|}{ lignocellulosic materials and surface area } \\
\hline Cellulose ${ }^{a, b}(\%)$ & 31.2 & 42.0 & - & - \\
\hline Hemicellulose ${ }^{a, b}(\%)$ & 30.1 & 25.0 & - & - \\
\hline $\operatorname{Lignin}^{\mathrm{a}, \mathrm{b}}(\%)$ & 33.5 & 23.1 & - & - \\
\hline BET surface area $\left(\mathrm{m}^{2} \mathrm{~g}^{-1}\right)$ & 10.6 & 14.7 & 89.7 & 182.5 \\
\hline
\end{tabular}

\footnotetext{
a Dry basis

${ }^{b}$ Dry and ash free basis
} 
When biomass is subjected to the action of heat at relatively high temperatures, it undergoes a transformation process in which all its components are extensively modified (Bridgwater, 2012; Virmond et al., 2013). The heat generated by this thermal degradation is responsible for the transformation of the rest of the biomass into coal. There are many chemical reactions that occur during the carbonization process, which are closely related to the temperature at which the biomass is subjected. Studies indicate that the lignin content in the biomass has a significant influence on the gravimetric yield of carbon obtained in the carbonization process, as well as on the content of fixed carbon and volatile material. The lignin content in sample 1 was 33.5\%. This material was a precursor for obtaining a coal with $55.7 \%$ fixed carbon.

It is observed in the Table 4 that the largest surface area was $182.5 \mathrm{~m}^{2} \mathrm{~g}-1$. This experiment was carried out under the following process conditions: temperature of $640^{\circ} \mathrm{C}$, heating rate $45^{\circ} \mathrm{C} / \mathrm{min}$, reaction time of $30 \mathrm{~min}$ and inert gas flow equal to $4 \mathrm{~mL} / \mathrm{min}$. During carbonization, the activated carbon pores are filled and blocked with tar or other thermal decomposition products and with some unstable and unstable carbons that may condense and form chemical bonds (Bridgwater, 2012; Virmond et al., 2013). At higher temperatures, these compounds are removed, increasing porosity and surface area, and the pores have different sizes and shapes. It is important to note that the adsorption efficiency of coal is not only regulated by factors such as its high surface area, but depends on the ability to adsorb a particular substance and the chemical and physical properties of coal (Bridgwater, 2012; Gamelin et al. 2009; Nascimento et al., 2017; Zhang et al., 2011). Activated carbons can be produced and modified in different ways to achieve different goals.

The spectrum in the infrared region of the biochar obtained in tree pruning pyrolysis can be seen in Fig. 2. The main characteristics are attributed to the presence of lignin, cellulose and hemicellulose in the material.

The spectrum absorbed by the tree pruning coal sample has the following bands: a broad and intense band at approximately $3500 \mathrm{~cm}^{-1}$ is attributed to the axial deformation of the $\mathrm{O}-\mathrm{H}$ group present in the structures of lignin, hemicellulose and cellulose; in $2919 \mathrm{~cm}^{-1}$ the band refers to the axial deformation of the $\mathrm{C}-\mathrm{H}$ group; the $1637 \mathrm{~cm}^{-1}$ band describes the vibrational stretch of the carbonyl group, i.e. presence of ketones, carboxylic acids and aldehydes present in the hemicellulose structure; a low intensity band around $1454 \mathrm{~cm}^{-1}$ is caused by the vibrational stretch of $\mathrm{C}=\mathrm{C}$ represented by alkenes and aromatic structures in the lignin structure. At $1034 \mathrm{~cm}^{-1}$ the band representing the angular deformation outside the plane of the $=\mathrm{C}-\mathrm{H}$ bonds is observed.

It is possible to observe a lower intensity of the carbonyl group compared to the axial deformation of the $\mathrm{O}-\mathrm{H}$ group.

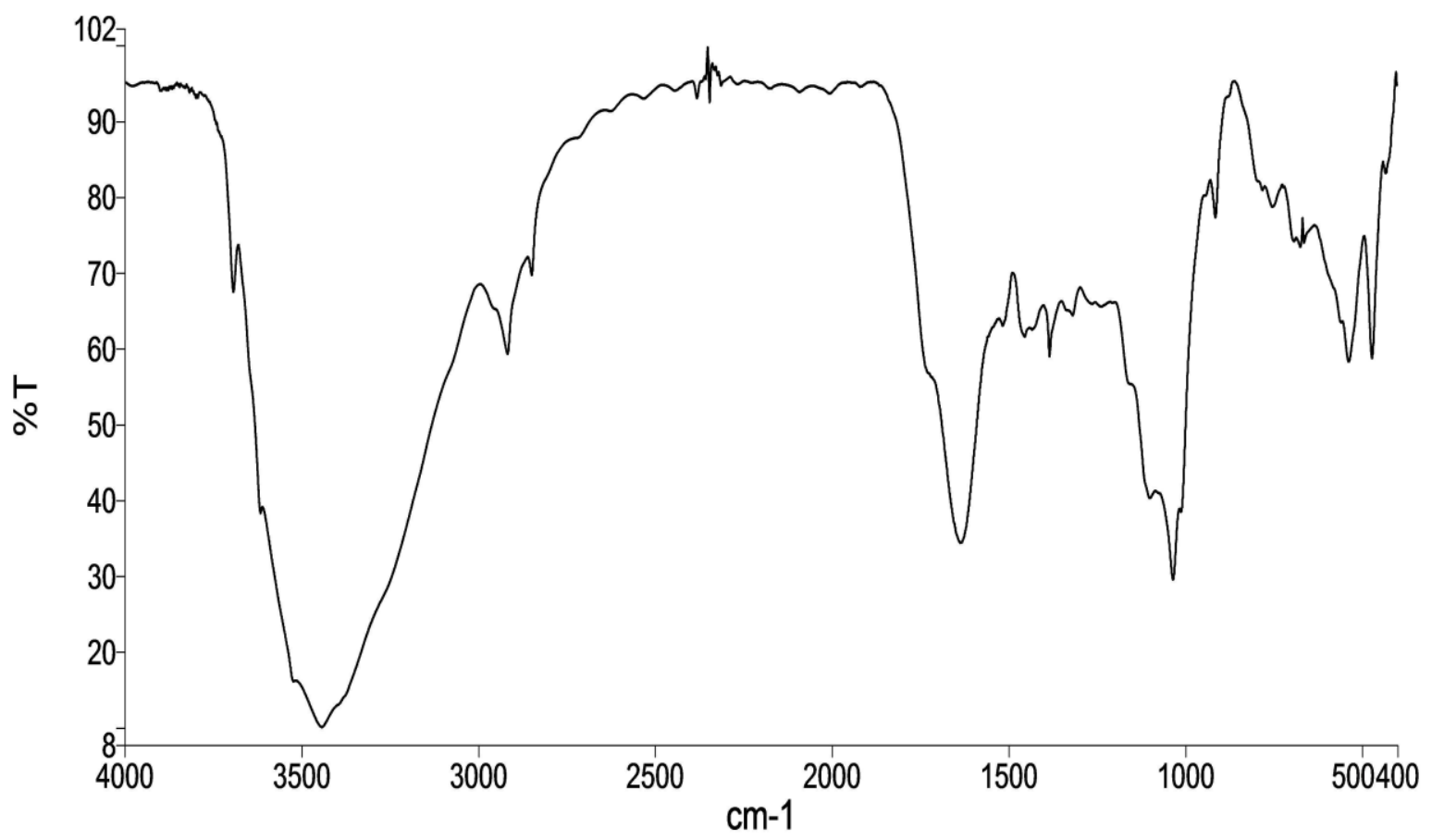

Figure 2. Spectrum infrared of sample of biochar obtained from the pyrolysis of tree pruning. 
According to Zhang et al. (2011), there is a relationship between the chemical structure of the coal and the composition of the other fractions of the pyrolysis process. The perceived reduction of the absorbance of the carbonyl group indicates a possible breakdown of the group bond, which gave rise to a large amount of $\mathrm{CO}$ and $\mathrm{CO}_{2}$ in the gas fraction. Zhang et al. (2011) produced coal at higher temperatures (800 and $1000{ }^{\circ} \mathrm{C}$ ) and observed that the absorbance of $\mathrm{CO}$ and $\mathrm{CH}$ of aromatics decreased markedly, indicating that cracking and reforming of aromatics were intensified by high temperature, with generation of a large amount of $\mathrm{H}_{2}$, indicating that the yield of the gas increased significantly as the temperature was raised from 600 to $1000^{\circ} \mathrm{C}$.

Scanning electron microscopy (SEM) was the technique used to observe the physical surface of the coal obtained from tree pruning pyrolysis (Fig. 3). The charcoal used in this analysis was obtained in a fixed bed reactor operated under the following conditions: pyrolysis temperature of $600{ }^{\circ} \mathrm{C}$, heating rate $30^{\circ} \mathrm{C} / \mathrm{min}$, reaction time of 30 minutes and inert gas flow rate equal to $4 \mathrm{~mL} / \mathrm{min}$.

According to Pedroza et al. (2014), pyrolysis confers a microporous structure to the coal obtained in the process with the potential of filtration and adsorption of organic and inorganic pollutants. It is important to note that according to literature (Paes et al., 2012), the properties of the products formed from pyrolysis suffer significant influence according to the temperature assigned to the process. Lignocellulosic materials with higher cellulose content in their composition show more pronounced and rapid volatilization, producing smaller amounts of biochar during pyrolysis (Bridgwater, 2012; do Vale et al., 2010, Paes et al., 2012). The rapid volatilization of the biomass results in the formation of biocharwith high porosity and reactivity coal. This is also favored by short residence times in rapid pyrolysis, which reduces contact between biochar and volatile materials. The main product obtained from the thermal degradation of lignin is biochar (Bridgwater, 2012; Nascimento et al., 2017). During the slow pyrolysis of large particles of lignocellulosic materials, they are converted into biochar by modifying their physical properties, such as porosity, thermal conductivity, etc. In a first stage, the temperature and the reaction time favor the decomposition of the less resistant compounds, changing the structure of the material. Prolonged heating and high temperatures can cause thermal degradation of biomass cell walls, leading to increased pore volume but reducing specific surface area (Bridgwater, 2012; doVale et al., 2010; Nascimento et al., 2017; Paes et al., 2012).

According to the presented images (Fig. 3) it is possible to identify a vast amount of pores with heterogeneous surface, with elongated cavities and oval shaped aperture. The high amount of pores can contribute with a greater surface area, being considered ideal for the lodging of chemical species during the adsorption process. According to the researchers (Bridgwater, 2012; Pedrosa et al., 2019), the promising use of coal is related to its physical and chemical characteristics, such as the ability to retain ions, porosity, specific surface, as well as its physical and chemical resistance. The factors that most influence the properties of the coal obtained in the pyrolysis process are divided into two parts: (a) characteristics of the precursor material (porosity, chemical composition and material density) and (b) process conditions (rate of heating, reaction time and temperature).
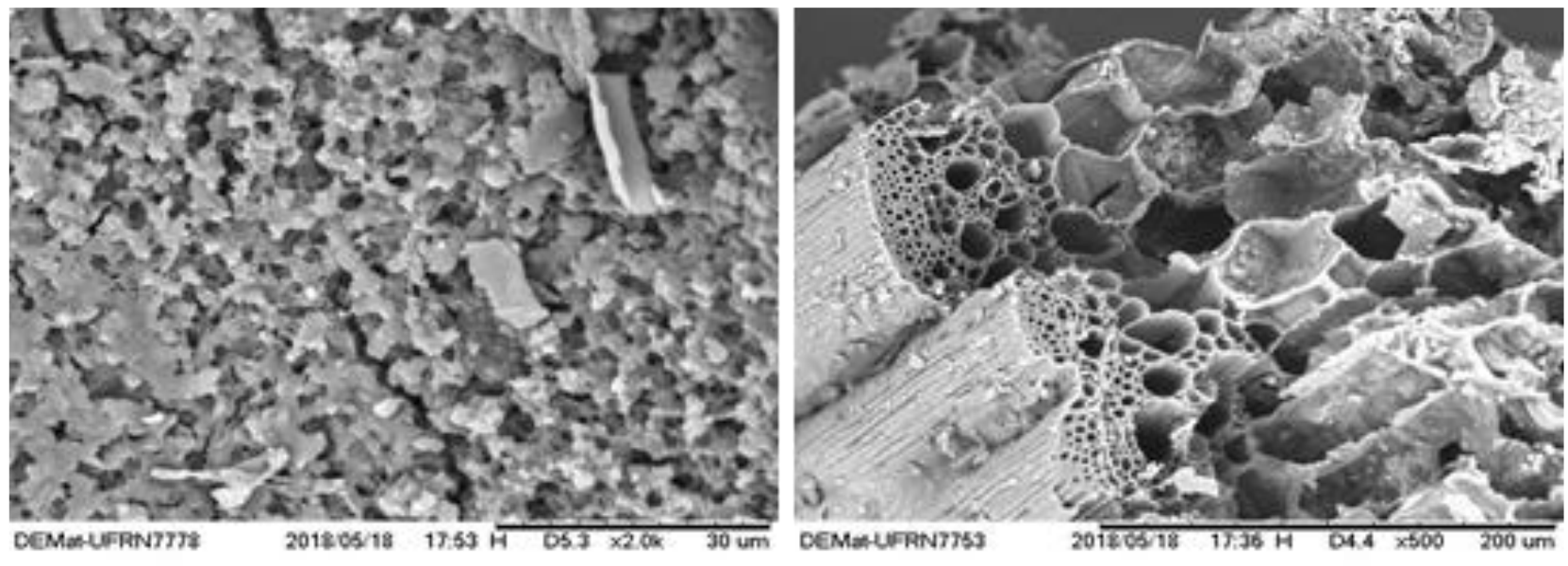

Figure 3. SEM images of biochar produced from pyrolysis of tree pruning. 
The thermal analysis data of the biomass under study are presented in Fig. 4. Through the analysis of the TG/DTG curves, it is possible to verify the reduction of humidity, which graphically demonstrated by the appearance of an event in the tree pruning sample, starting at $40^{\circ} \mathrm{C}$ and finishing at around $160^{\circ} \mathrm{C}$, corresponding to the loss of water. This event is well above the boiling point of water, and according to some researchers, this is due to the fact that materials with higher ash content in their chemical composition have the maximum release of volatiles at higher temperatures (Kosanić et al., 2014; Neves et al., 2014). The tree pruning sample contains many inorganic materials (sand, silt, soil), favoring the dilution of the organic material which may cause a delay in heat transfer into the particles and hence the diffusion of volatiles during pyrolysis of biomass (Bridgwater, 2012; Pedroza et al., 2017). The percentage loss of mass at $110^{\circ} \mathrm{C}$ was $6,8 \%$, a value very close to that obtained for the moisture content of this sample in the classical gravimetric analysis (6,6\%).
Then two organic matter decomposition events are observed, the first being around 200 and $400{ }^{\circ} \mathrm{C}$ and the second between 420 and $600{ }^{\circ} \mathrm{C}$. A decrease in the thermal degradation of the sample is observed at $600^{\circ} \mathrm{C}$. A decrease in the ash content of the material is observed with increasing temperature and this is due to the breakdown of inorganic carbon bonds present in the form of carbonate and bicarbonate ions, chemical decomposition of oxides, as well as the thermal degradation of lignin. According to Pedroza et al. (2014), the degradation of lignin begins at relatively low temperatures, and continues to occur up to about $850^{\circ} \mathrm{C}$. Virmond etal. (2013) report that mass losses occurring at temperatures below $600^{\circ} \mathrm{C}$ may be associated with thermal degradation of organic matter, and losses occurring above $600{ }^{\circ} \mathrm{C}$ to the decomposition of the inorganic material present in the residual biomass. According to Bridgwater (2012), the thermal decomposition of some families of compounds occurs in well-defined temperature ranges, and that compounds with oxygen in the molecule degrade at higher temperatures than other non-oxygenated compounds.

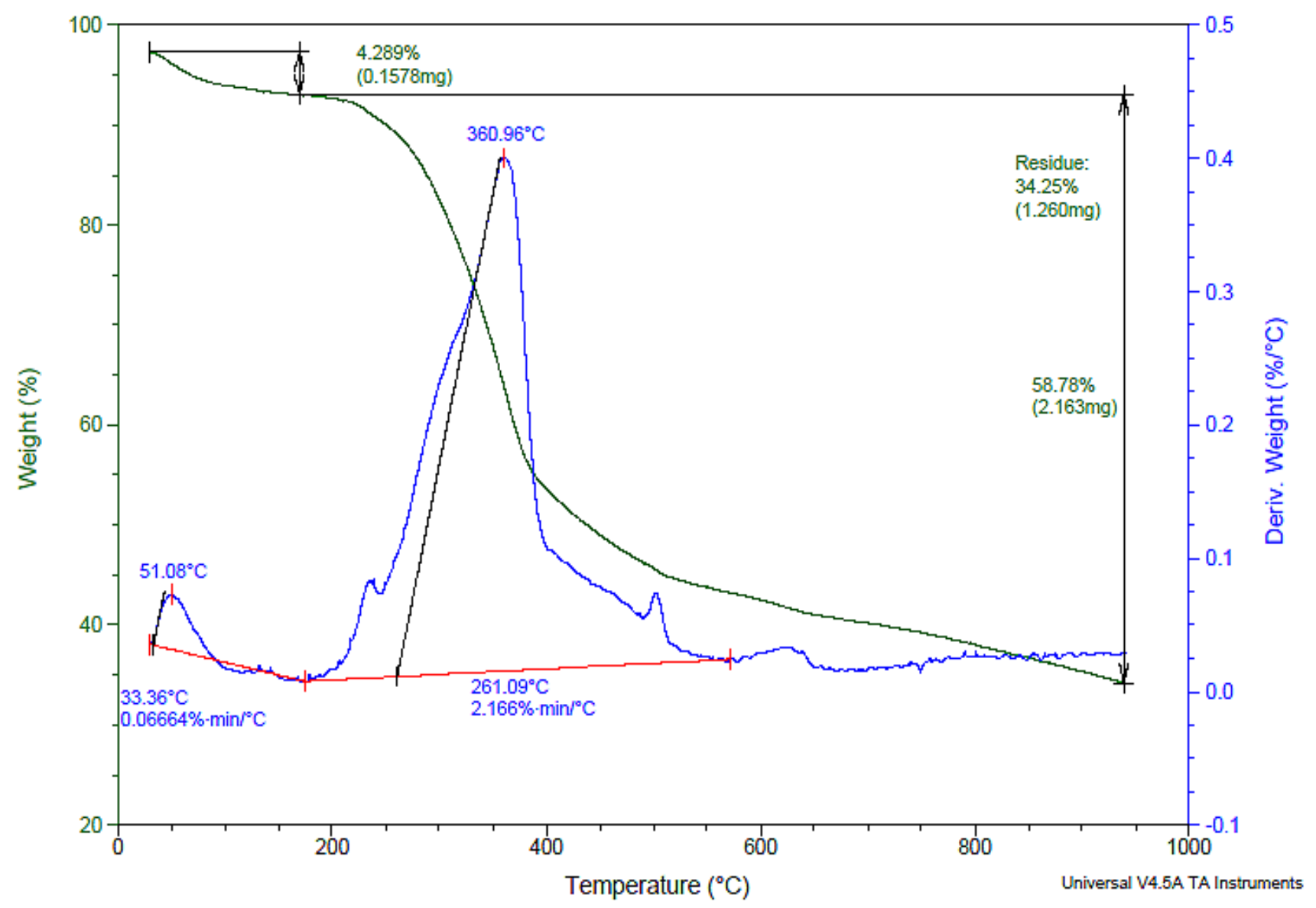

Figure 4. Thermogravimetric curve of tree pruning sample. 
The crude material was subjected to kinetic mass loss in an oven at $50{ }^{\circ} \mathrm{C}$ (Fig. 5). According to the observation of the experimental data, a linear growth of material loss occurs in the first hours of drying. During the first five hours of the experiment the residue lost about $44.6 \%$ of its initial mass. After $20 \mathrm{~h}$ hours the sample remained with less than $50 \%$ of the starting material. As indicated by Pedroza et al. (2017), 23.33\% of the urban garbage produced by the cities are public garbage, which includes "green garbage", consisting of branches, trunks and leaves, as a result of cleaning services of squares, streets and land. Palmas, capital of Tocantins, has a monthly production of approximately 7,500 tons of urban solid waste. Of this total, 1.8 tons are public cleaning waste, which includes tree pruning waste, and final disposal of the residues of pruning the municipal sanitary landfill (Pedrosa et al., 2019).

\subsection{Yields of biochar obtained during pyrolysis of tree pruning (initial tests)}

The experimental data obtained in the initial pruning pyrolysis tests of trees are presented in Table 5 and represent the production of biochar in the system. The t-test was applied simulating equivalent variances in the two treatments studied, in order to verify the existence or not of a significant difference between them (Table 6).

The data observed in Table 6 indicate that there are no significant differences in the average of coal production in the pyrolysis process of tree pruning in the two treatments (temperatures of 500 and $600{ }^{\circ} \mathrm{C}$ ) at the $95 \%$ confidence level. This indicates that the pyrolysis reactor can be operated at a lower temperature, which represents process energy saving.

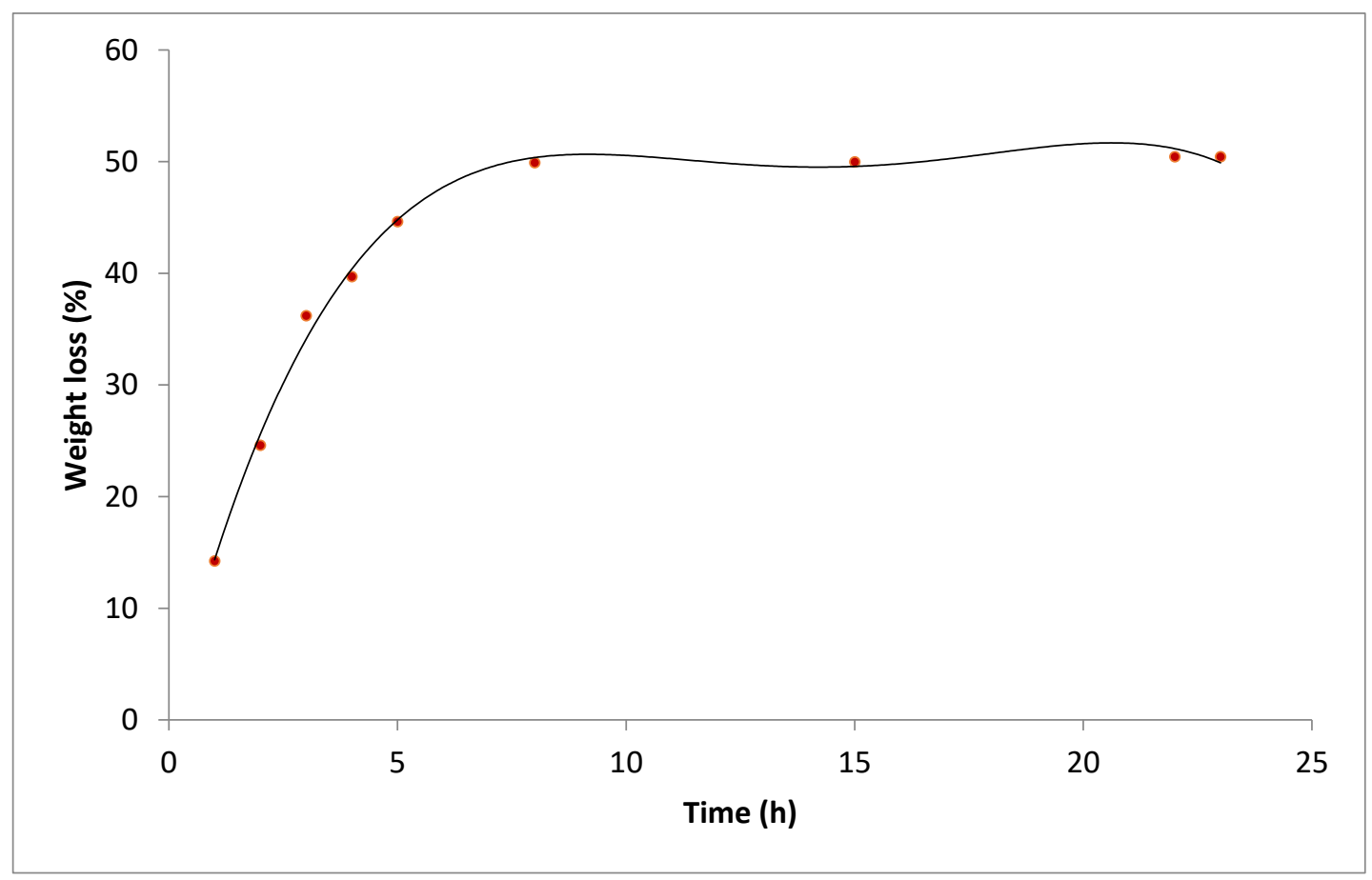

Figure 5. Study of biomass mass loss at $40^{\circ} \mathrm{C}$.

Table 5. Biochar yield data obtained during tree pruning pyrolysis tests.

\begin{tabular}{ccc}
\hline Experiments & \multicolumn{2}{c}{ Temperature $\left({ }^{\circ} \mathrm{C}\right)$} \\
\cline { 2 - 3 } & 500 & 600 \\
\hline 1 & 35.32 & 34.17 \\
2 & 32.20 & 34.17 \\
3 & 35.57 & 32.87 \\
4 & 32.63 & 27.06 \\
\hline Mean & 33.93 & 32.07 \\
\hline Standard deviation & 1.76 & 3.39 \\
\hline Degrees of freedom & 3 & 3 \\
\hline
\end{tabular}


Table 6. Statistical analysis through the t-test simulating equivalent variances for the production of biochar during the pyrolysis of tree pruning.

\begin{tabular}{lrr}
\hline & $500{ }^{\circ} \mathrm{C}$ & $600{ }^{\circ} \mathrm{C}$ \\
\hline Mean & 33.93 & 32.07 \\
Variance & 3.101533333 & 11.520025 \\
Observations & 4 & 4 \\
pooled variance & 7.310779167 & \\
Hypothesis of the mean difference & 0 & \\
Gl & 6 & \\
Stat t & 0.974158101 & \\
$\mathrm{P}(\mathrm{T}<=\mathrm{t})$ one-tailed test. & 0.183799946 & \\
Critical value t: one-tailed test & 1.943180281 & \\
$\mathrm{P}(\mathrm{T}<=\mathrm{t})$ two-tailed test & 0.367599891 & \\
Critical value t: two-tailed test & 2.446911851 & \\
\hline
\end{tabular}

According to Pedroza et al. (2014), the reactions that occur during the pyrolysis process are totally correlated with the temperature at which the biomass is submitted. The temperature is a parameter that influences the performance in coal, liquids and non-condensable gases, and the higher the temperature, the greater the degree of thermal decomposition of the biomass, with consequent increase in the quantity of liquids and gases and, consequently, lower coal yield (Paes et al., 2012). According to do Vale et al. (2010), in the carbonization process a higher coal yield is expected, since the smoke is not recovered for other uses in most pyrolysis plants. Coal yields, condensate and noncondensate are affected by the conditions under which biomass is carbonized.

\subsection{Experimental results obtained in the central composite rotatable design (CCRD)}

The experimental results obtained in the CCRD planning are presented in Table 7 . In this planning the following factors were investigated: reactor temperature $\left({ }^{\circ} \mathrm{C}\right)$ and heating rate $\left({ }^{\circ} \mathrm{C} / \mathrm{min}\right)$. The percentage yields of biochar were considered the experimental planning responses.

Pareto diagram (Fig. 6) generated from the experimental data indicates that the temperature had a negative effect on the production of biochar. These data show that the increase in temperature from 360 to $640{ }^{\circ} \mathrm{C}$ favored a decrease in the generation of coal in the process.

Table 8 shows the regression coefficients of the variables studied in obtaining coal during tree pruning pyrolysis. The interaction effect between the variables was also considered. Significant effects were highlighted (at a 95\% confidence (evel).
The final carbonization temperature of the biomass plays a very important role in the various chemical reactions involved during the pyrolysis and influence the chemical and physical characteristics of the products generated (do Vale et al., 2010; Mohan et al., 2006).

For many types of biomass, the increase in temperature and reaction time reduces the final production of both volatile and liquid compounds, as well as charcoal. However, these associated factors favor the increase of the structural organization of the coal produced, increasing its physical and chemical resistance (Mašek et al., 2013). The devolatilization is the first step for the production of the biochar by thermal processes, from the individual components of the biomass cellulose, hemicellulose and lignin (Bridgwater, 2012; Pedroza et al., 2014).

The secondary reactions occurring in the reactor during the thermal degradation process of the biomass influence the yield of coal obtained. According to Mašek et al. (2013), high ash content, especially potassium, sodium and calcium, can act as catalysts for the pyrolysis process, promoting secondary reactions of volatile decomposition and formation of coal fines. The sample comprised of leaves of trees had a much higher ash content than that of sample 2, 6.5\%, and this can be attributed to the presence of soil and dust in sample 1 , since the material was directly in contact with the soil. According to Patwardhan et al. (2011), the low production of bio-oil for prolonged residence times is attributed to secondary reactions of cracking and polymerization of the volatiles to the gases and coal fines, respectively. According to Rutkowski (2011), when the pyrolysis temperature is increased, the production of monomers is lower because of the presence of secondary reactions, and there is a significant increase in gas production. For Patwardhan et al. (2011), an 
important aspect must be considered when primary decomposition is studied, is that the effects of secondary reactions should be minimized. However, it is not always possible to separate the two classes of reactions. To limit the secondary reactions of the volatile material, the temperature should be kept below $500^{\circ} \mathrm{C}$.
The highest biochar yield was observed in test 8 (60.10\%), and this experiment was operated under the conditions: (a) system temperature $360^{\circ} \mathrm{C}$ and (b) heating rate of $45^{\circ} \mathrm{C} / \mathrm{min}$. The lowest yield $(24.50 \%)$ was obtained with the experimental conditions (system temperature $=640^{\circ} \mathrm{C}$ and $45^{\circ} \mathrm{C} / \mathrm{min}$ of heating rate).

Table 7. Results of the central composite rotatable design for the production of tree pruning coal.

\begin{tabular}{cccc}
\hline Experiments & \multicolumn{2}{c}{ Factors } & Biochar yields (\%) \\
\cline { 2 - 3 } & Temperature $\left(\mathrm{X}_{1}\right)\left({ }^{\circ} \mathrm{C}\right)$ & $\begin{array}{c}\text { Heating rate }\left(\mathrm{X}_{2}\right) \\
\left({ }^{\circ} \mathrm{C} / \text { min }\right)\end{array}$ & \\
\hline 1 & 400 & 30 & 57.50 \\
2 & 600 & 30 & 26.70 \\
3 & 400 & 60 & 55.10 \\
4 & 600 & 60 & 33.50 \\
5 & 500 & 45 & 52.10 \\
6 & 500 & 45 & 52.50 \\
7 & 500 & 45 & 52.70 \\
8 & 360 & 45 & 60.10 \\
9 & 500 & 66 & 32.50 \\
10 & 640 & 45 & 24.50 \\
11 & 500 & 24 & 41.30 \\
\hline
\end{tabular}

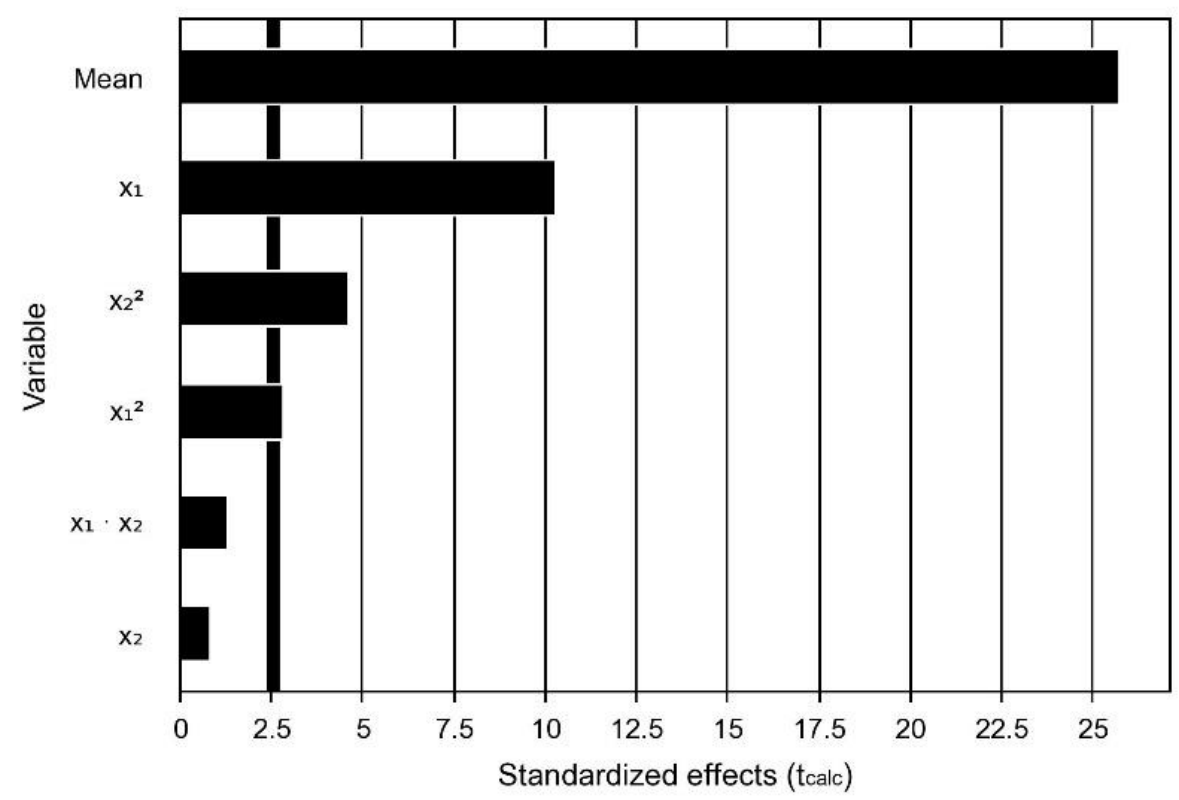

Figure 6. Representation of the Pareto diagram. 
Marcelo M. Pedroza et al. / Journal of Applied Research and Technology 49-65

Table 8. Regression Coefficients obtained from the production of biochar

in pyrolysis system of pruning of trees, in a confidence interval of 95\%.

\begin{tabular}{ccccc}
\hline Factors & Coefficient & Standard Error & Calculated T & p-value \\
\hline Mean & 52.43 & 2.03 & 25.77 & 0.0000 \\
$X_{1}$ & -12.84 & 1.25 & -10.31 & 0.0001 \\
$X_{1}{ }^{2}$ & -4.17 & 1.48 & -2.81 & 0.0376 \\
$X_{2}$ & -1.01 & 1.25 & -0.81 & 0.4563 \\
$X_{2}{ }^{2}$ & -6.87 & 1.48 & -4.63 & 0.0057 \\
$X_{1} \cdot X_{2}$ & 2.30 & 1.76 & 1.31 & 0.2487 \\
\hline
\end{tabular}

With the regression coefficients, obtained from the coded matrix, it was possible to write the adjusted model that describes the biochar obtaining during pyrolysis of biomass empirically, according to Equation 1.

Biochar yield $(\%)=52.43-12.84 X_{1}-1.01 X_{2}-4.17 X_{1}^{2}-6.87 X_{2}^{2}+$ $2.30 \mathrm{X}_{1} \cdot \mathrm{X}_{2}$

Where: $\mathrm{X}_{1}=$ Temperature $\left({ }^{\circ} \mathrm{C}\right) ; \mathrm{X}_{2}=$ heating rate $\left({ }^{\circ} \mathrm{C} / \mathrm{min}\right)$ (in coded values)

Table 9 shows the analysis of variance (ANOVA) for the production of biochar in the pyrolysis of tree pruning.

Table 9. ANOVA for the production of coal in process of pyrolysis of tree pruning.

\begin{tabular}{lccccc}
\hline $\begin{array}{l}\text { Variation } \\
\text { source }\end{array}$ & $\begin{array}{l}\text { Sum of } \\
\text { squares }\end{array}$ & $\begin{array}{l}\text { Degrees } \\
\text { of } \\
\text { freedom }\end{array}$ & $\begin{array}{l}\text { Mean } \\
\text { square }\end{array}$ & $F_{\text {calc }}$ & P-value \\
\hline Regression & 1643.6 & 5 & 328.7 & 26.5 & 0.00132 \\
Residuals & 62.1 & 5 & 12.4 & & \\
Lack of fit & 61.9 & 3 & 20.6 & 221.1 & 0.00451 \\
Pure error & 0.2 & 2 & 0.1 & & \\
$\quad$ Total & 1705.7 & 10 & & & \\
\hline
\end{tabular}

$R^{2}=0.9636 ; F_{\text {tab }}(5 ; 5 ; 0,05)=5.05$

The coefficient $\mathrm{R}^{2}$ obtained by the regression was 0.9636 , indicating a good adjustment of the model, justified by the considerable agglomeration of points near the representative line (Fig. 7). To confirm the significance of the model parameters by ANOVA analysis (Table 9), the $F$ test was performed. To be statistically significant, the $F$ value obtained from the regression should be greater than the $F_{\text {tab }}$ value. The value of $F_{\text {calc }}$ was determined by the expression, $F_{\text {calc }}=$ Mean Square regression / Mean Square residuals. Comparing the value of $F_{\text {calc }}(26.5)$ for the regression with the $F_{\text {tab }}$ value $\left(F_{\text {tab }}=\right.$ 5.05), there is a significant regression.
Therefore, the experimental data are well represented by the adjusted model, that is, the model obtained for the significant variables can be used for predictive purposes within the domain of the factors studied. In this case, it is then possible to construct the response surface and contour curves with the experimental data obtained. The maximum amount of biochar was obtained under low temperature conditions, as observed in the response surface generated by the model (Fig. 8).

\subsection{Study of the dye removal in a biochar filter obtained during tree pruning pyrolysis}

The experimental data obtained during the operation of the biochar filter used in the filtration of the methylene blue dye are shown in Fig. 9. The filter presented maximum dye removal values at times of 200 and 700 min for the filtration flows of 5 and $2 \mathrm{~mL} / \mathrm{min}$, respectively. Figure 9 also shows a decline in efficiency due to coal saturation. The lowest observed efficiency was $85 \%$ for the $2 \mathrm{~mL} / \mathrm{min}$ flow, with an operating time of 800 minutes. This decrease in efficiency may be associated with the saturation effect as well as the filtration flow employed.

Rahman et al. (2012) studied the removal of the methylene blue dye in a descending filter consisting of activated carbon produced from the pyrolysis of rice hulls. In this research was studied the effect of the flow rate being evaluated the removal of the dye in the system. The researchers employed three levels for the flows: 1.0, 1.4 and $1.8 \mathrm{~mL} / \mathrm{min}$. According to research data, the removal efficiency decreases with increasing flow rate. About $98.43 \%$ of methylene blue was removed in the flow $1.0 \mathrm{~mL} / \mathrm{min}$. For the flows of 1.4 and 1.8 $\mathrm{mL} / \mathrm{min}$ the dye removal was 96.81\%. According to the researchers (Dawood et al., 2018; Makrigianni et al., 2017; Shafeeyan et al., 2015; Song et al., 2011), this phenomenon may be due to the fact that when the flow velocity of the dye was lower, the longer the contact time of the methylene blue with the active surface of the adsorbent. 


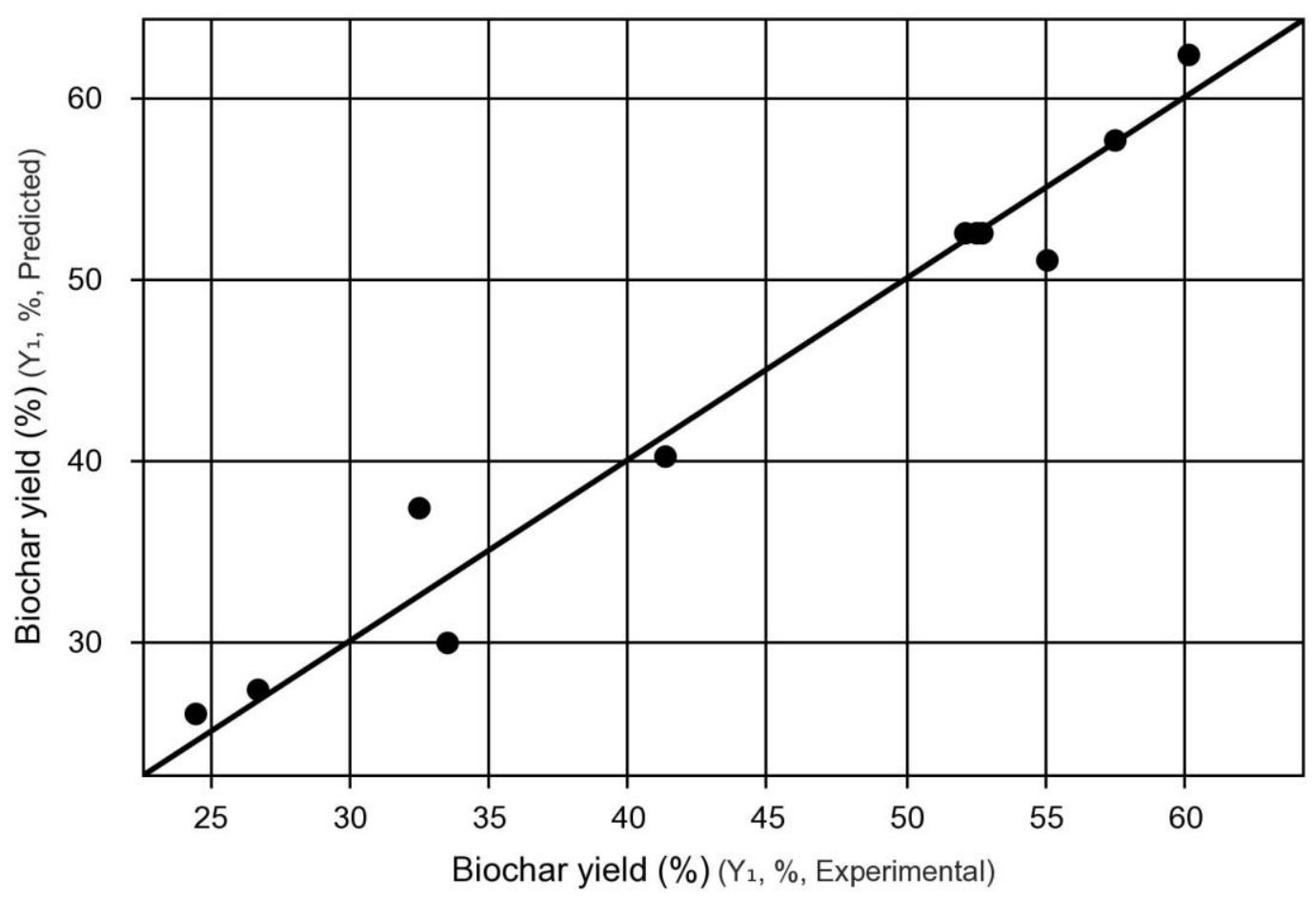

Figure 7. Observed values versus values predicted by the model.

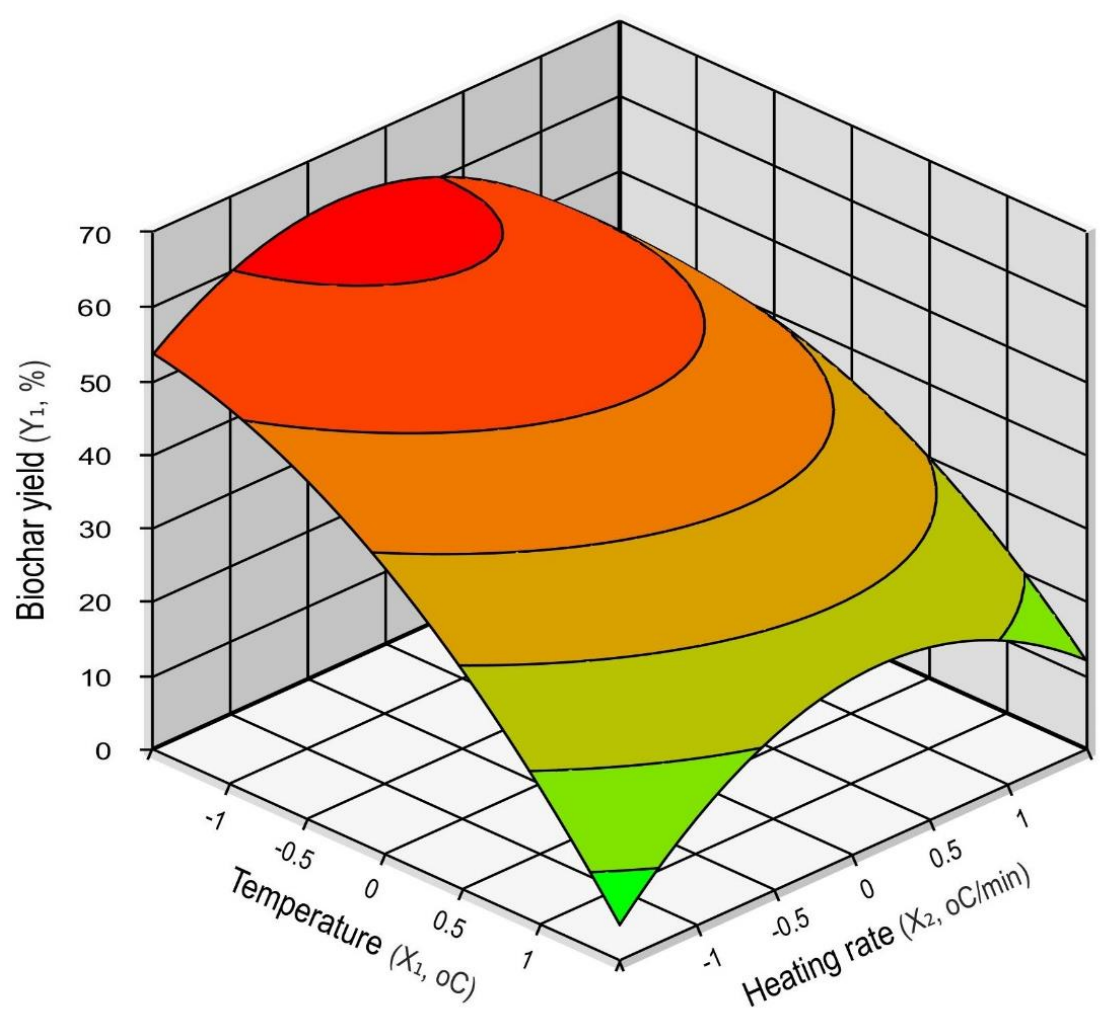

Figure 8. Response surface for the pyrolysis of tree pruning for biochar production. 


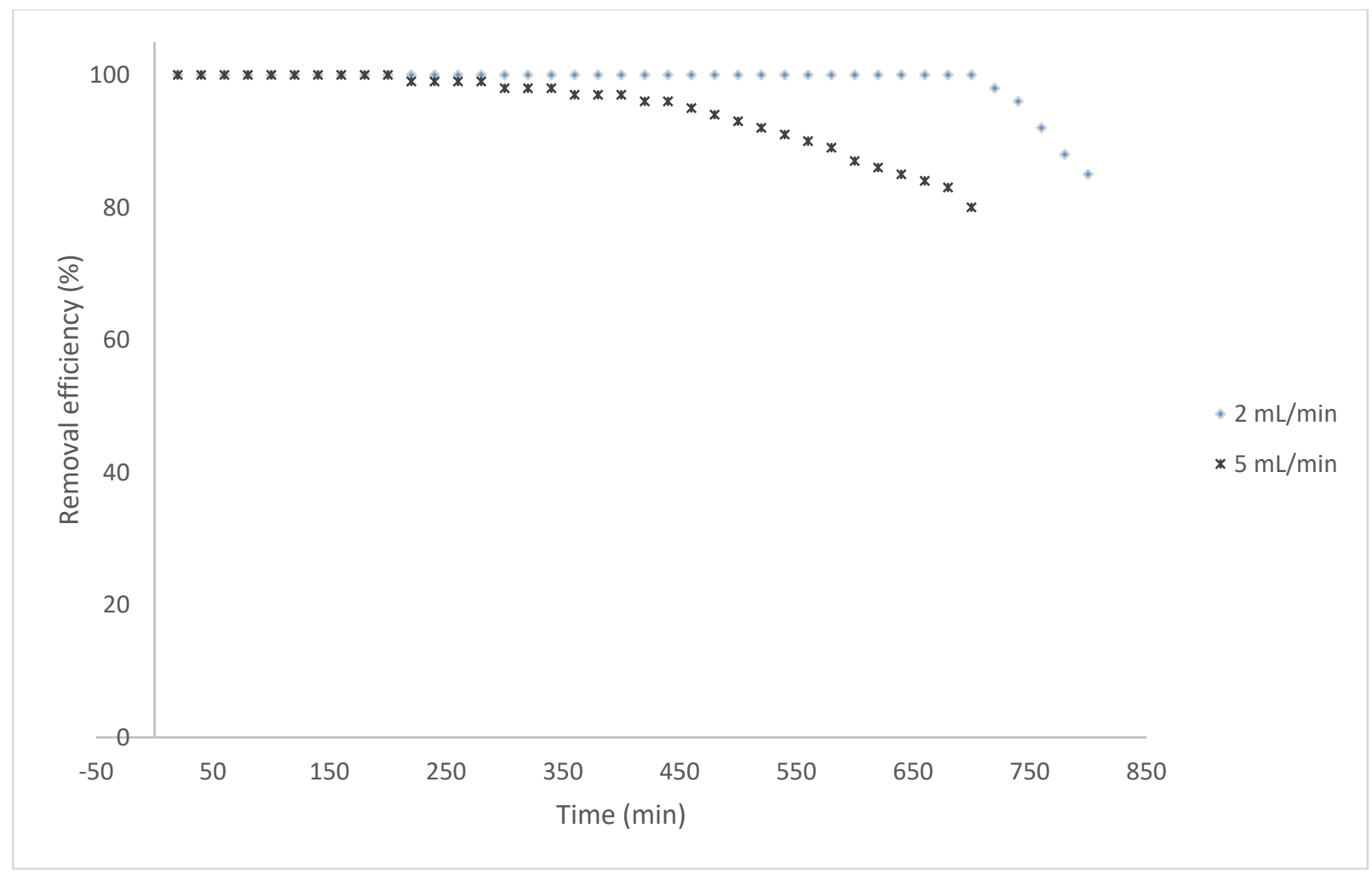

Figure 9. Efficiency of removal of methylene blue dye in tree pruning biochar filter.

\subsection{Efficiency of activated charcoal obtained from tree pruning in the treatment of gray water}

Table 10 presents the results obtained during the gray water polishing process in coagulation/flocculation/decantation system and filtration by charcoal obtained from tree pruning pyrolysis.

During the coagulation/flocculation/decantation step a good removal of turbidity particles from gray water was observed using an aluminum sulfate dosage of $200 \mathrm{mg} / \mathrm{L}$. The total solids, fixed solids, volatile solids and turbidity removal values in this treatment step were, respectively, 58, 50, 80 and 95\%.

By comparing the values of the analytical parameters studied in the samples of raw gray water and effluent after filtering on charcoal filter from tree pruning, it is possible to obtain the removal efficiency of each parameter. The removal values of the turbidity, COD, Total Solids and residual chlorine parameters were 99.5, 98, 71 and $100 \%$, respectively. The charcoal filter was responsible for the final step of removal of putrescent organic matter present in the gray waters. The charcoal filter was responsible for the removal of $87 \%$ of COD.

The polishing process employed here removed $64 \%$ of fixed solids present in gray water. This low removal compared to the other analytical parameters studied is related to the low retention capacity of inorganic ions, abundant in the gray water samples (especially sodium), on the surface of the coal used in this research (Pedroza et al., 2020). 
Marcelo M. Pedroza et al. / Journal of Applied Research and Technology 49-65

Table 10. Results obtained during gray water polishing in a filtration system containing activated charcoal produced from tree pruning pyrolysis.

\begin{tabular}{c|c|c|c|c}
\hline \multirow{2}{*}{ Analytical parameter } & \multicolumn{4}{|c}{ Results } \\
\cline { 2 - 5 } & P1 & P2 & P3 & P4 \\
\hline pH (-) & 25.1 & 25.0 & 25.0 & 24.9 \\
Temperature ( $\left.{ }^{\circ} \mathrm{C}\right)$ & 9.8 & 7.0 & 6.7 & 6.4 \\
Turbidity (uT) & 170 & 8.7 & 1.2 & 0.7 \\
Total solids (mg/L) & 450.5 & 120.6 & 45.7 & 5.8 \\
Fixed solids (mg/L) & 2340 & 978 & 788 & 679 \\
Volatile solids (mg/L) & 1690 & 845 & 706 & 601 \\
Alkalinity (mgCaCO $/$ L) & 650 & 133 & 82 & 78 \\
Residual chlorine (mg/L) & 412 & 105 & 89 & 78 \\
\hline
\end{tabular}

\section{Conclusions}

Based on the experimental data obtained from this scientific research, the following conclusions can be drawn:

- Temperature had a negative effect on the coal production process, indicating that the increase in temperature favors the decrease in coal yield. The same effect was observed for the pyrolysis reactor heating rate.

- The charcoal obtained from tree pruning presents great adsorption capacity of the methylene blue dye, and the adsorption power is dependent on the liquid flow employed in the filtration column.

- During the treatment of gray water, tree pruning coal played an important role in removing the compounds responsible for the characteristic odor of the material in question. The coal acted as a polishing of the effluent by removing the COD and residual chlorine from the liquid.

\section{References}

Albalawneh, A., \& Chang, T. K. (2015). Review of the greywater and proposed greywater recycling scheme for agricultural irrigation reuses. International Journal of ResearchGranthaalayah, 3(12), 16-35.

https://doi.org/10.29121/granthaalayah.v3.i12.2015.2882

American Public Health Association, American Water Works Association, Water Pollution Control Federation, \& Water Environment Federation. (1912). Standard methods for the examination of water and wastewater (Vol. 2). American Public Health Association.

Bani-Melhem, K., Al-Qodah, Z., Al-Shannag, M., Qasaimeh, A., Qtaishat, M. R., \& Alkasrawi, M. (2015). On the performance of real grey water treatment using a submerged membrane bioreactor system. Journal of Membrane Science, 476, 40-49.

https://doi.org/10.1016/j.memsci.2014.11.010 
BRASIL (2 de agosto de 2010) Política Nacional de Resíduos Sólidos No 12.305.Presidência da República, Departamento da Casa Civil. Brasília.

Bridgwater AV (2012) Review of fast pyrolysis of biomass and product upgrading. Biomass and Bioenergy 38: 68-94. https://doi.org/10.1016/j.biombioe.2011.01.048

Cheng, X., Tang, Y., Wang, B., \& Jiang, J. (2018). Improvement of charcoal yield and quality by two-step pyrolysis on rice husks. Waste and Biomass Valorization, 9(1), 123-130.

https://doi.org/10.1007/s12649-016-9736-5

Dawood, S., Sen, T. K., \& Phan, C. (2018). Performance and dynamic modelling of biochar and kaolin packed bed adsorption column for aqueous phase methylene blue (MB) dye removal. Environmental technology, 40(28).

https://doi.org/10.1080/09593330.2018.1491065

Gamelin, F. X., Baquet, G., Berthoin, S., Thevenet, D., Nourry, C., Nottin, S., \& Bosquet, L. (2009). Effect of high intensity intermittent training on heart rate variability in prepubescent children. European journal of applied physiology, 105(5), 731-738.

https://doi.org/10.1007/s00421-008-0955-8

Kan T, Strezov V, Evans TJ (2016) Lignocellulosic biomass pyrolysis: A review of product properties and effects of pyrolysis parameters. Renewable and Sustainable Energy Reviews, 57: 1126-1140.

https://doi.org/10.1016/j.rser.2015.12.185

Kosanić, T. R., Ćeranić, M. B., Đurić, S. N., Grković, V. R., Milotić, M. M., \& Brankov, S. D. (2014). Experimental investigation of pyrolysis process of woody biomass mixture. Journal of Thermal Science, 23(3), 290-296.

https://doi.org/10.1007/s11630-014-0709-3

Makrigianni V, Giannakas A, Hela D, Papadaki M, Konstantinou I (2017) Adsorption of methylene blue dye by pyrolytic tire char in fixed-bed column. Desalination and water treatment 65:346-358.

https://doi.org/10.5004/dwt.2017.20340

Mašek O, Budarin V, Gronnow M, Crombie K, Brownsort P, Fitzpatrick E, Hurst P (2013) Microwave and slow pyrolysis biochar-Comparison of physical and functional properties. Journal of Analytical and Applied Pyrolysis, 100, 41-48

https://doi.org/10.1016/j.jaap.2012.11.015
Mohan, D., Pittman Jr, C. U., \& Steele, P. H. (2006). Pyrolysis of wood/biomass for bio-oil: a critical review. Energy \& fuels, 20(3), 848-889.

https://doi.org/10.1021/ef0502397

Nascimento P.F.P, Sousa J. F., Oliveira J. A., Possa R.D., Santos L.S., Carvalho F.C., Ruiz J.A.C., Pedroza M.M., Bezerra M.B.D. (2017) Wood sawdust and sewage sludge pyrolysis chars for $\mathrm{CO}_{2}$ adsorption using a magnetic suspension balance. Canadian Journal of Chemical Engineering, 95(11), 2148-2155.

https://doi.org/10.1002/cjce.22861

Neves D, Thunman H, Matos A, Tarelho L, Gómez-Barea A (2011) Characterization and prediction of biomass pyrolysis products. Progress in Energy and Combustion Science, 37(5), 611-630.

https://doi.org/10.1016/j.pecs.2011.01.001

Paes, J. B., de Lima, C. R., de Oliveira, E., \& dos Santos, H. C. M. (2012). Rendimento e caracterização do carvão vegetal de três espécies de ocorrência no semiárido brasileiro. Revista Ciência da Madeira (Brazilian Journal of Wood Science), 3(1), 10-12953.

Patwardhan PR, Dalluge DL, Shanks BH, Brown RC (2011) Distinguishing primary and secondary reactions of cellulose pyrolysis. Bioresource Technology 102(8), 5265-5269.

https://doi.org/10.1016/j.biortech.2011.02.018

Pedrosa, A. L., Pedroza, M. M., \& Cavallini, G. S. (2019). Posttreatment of paint industry effluents by filtration using Andropogon biochar (Andropogon gayanus Kunth CV. Planaltina). Environmental Science and Pollution Research, 26(32), 33294-33303.

https://doi.org/10.1007/s11356-019-06463-6

Mendes Pedroza, M.., Gama Vieira, G. E., \& Fernandes de Sousa, J. (2011). Características químicas de lodos de esgotos produzidos no Brasil. Revista AIDIS de Ingeniería y Ciencias Ambientales. Investigación, Desarrollo y Práctica, 4(2), 35-47.

Manna, S (2018) Treatment of Gray Water for Reusing in Nonpotable Purpose to Conserve Water in India. International Journal of Applied Environmental Sciences, 13(8), 703-716.

Pedroza, M. M., Sousa, J. F., Vieira, G. E. G., \& Bezerra, M. B. D. (2014). Characterization of the products from the pyrolysis of sewage sludge in $1 \mathrm{~kg} / \mathrm{h}$ rotating cylinder reactor. Journal of Analytical and Applied Pyrolysis, 105, 108-115.

https://doi.org/10.1016/j.jaap.2013.10.009 
Pedroza, M. M., Souza, J. F., Vieira, G. E. G., \& Bezerra, M. B. D. (2017). Bio-oil and biogas from the pyrolysis of sewage sludge, and non-isothermal degradation on Usy Zeolite. Brazilian Journal of Petroleum and Gas, 11(3). 149-163.

Pedroza MM, Figueiredo Junior CA, Rodrigues CR, Arruda MG, Paz ECS, Lôbo RN (2020) Gray water treatment through the coagulation/decantation/filtration/adsorption process. Revista de Engenharia e Tecnologia 12: 139-148.

Rahman MA, Amin SMR, Alam MAS (2012) Removal of Methylene Blue from Waste Water Using Activated Carbon Prepared from Rice Husk. Dhaka Univ. J. Sci. 60, 185-189.

https://doi.org/10.3329/dujs.v60i2.11491

Rutkowski P (2011) Pyrolysis of cellulose, xylan and lignin with the $\mathrm{K}_{2} \mathrm{CO}_{3}$ and $\mathrm{ZnCl}_{2}$ addition for bio-oil production. Fuel Processing Technology 92: 517-522.

https://doi.org/10.1016/j.fuproc.2010.11.006

Shafeeyan MS, Daud WMAW, Shamiri A, Aghamohammadi N (2015) Adsorption equilibrium of carbon dioxide on ammoniamodified activated carbono. Chemical Engineering Research and Design, 104, 42-52.

https://doi.org/10.1016/j.cherd.2015.07.018

Song J, Zou W, Bian Y, Su F, Han R (2011) Adsorption characteristics of methylene blue by peanut husk in batch and column modes. Desalination 265 (1-3), 119-125.

https://doi.org/10.1016/j.desal.2010.07.041

Vale, A. T. D., Dias, Í. S., \& Santana, M. A. E. (2010). Relações entre propriedades químicas, físicas e energéticas da madeira de cinco espécies de cerrado. Ciência Florestal, 20(1), 137-145. http://doi.org/10.5902/198050981767

Vieira GEG, Romeiro GA, Sella SM, Damasceno RN, Pereira RG (2009) Low temperature conversion (LTC) - An alternative method to treat sludge generated in an industrial wastewater treatment station - Batch and continuous process comparison. Bioresource technology, 100(4), 1544-1547.

https://doi.org/10.1016/j.biortech.2008.08.040

Virmond E, Rocha JD, Moreira RFPM, José HJ (2013) Valorization of agroindustrial solid residues and residues from biofuel production chains by thermochemical conversion: a review, citing Brazil as a case study. Brazilian Journal of Chemical Engineering 30(2), 197-230.

https://doi.org/10.1590/S0104-66322013000200001
Zhang B, Xiong S, Xiao B, Yu D, Jia X (2011) Mechanism of wet sewage sludge pyrolysis in a tubular furnace. International Journal oh Hydrogen Energy 36(1), 355-363.

https://doi.org/10.1016/j.ijhydene.2010.05.100 